June 2016, Revised August 2016

\title{
Extraction Response of Skirted Foundations and a Spudcan on Sand-Over-Clay Deposits
}

\author{
Muhammad Shazzad Hossain1, Yuxia $\mathrm{Hu}^{2}$ and Darmawan Ekaputra ${ }^{3}$
}

${ }^{1}$ Corresponding Author, Senior Research Fellow (BEng, MEng, PhD, MIEAust), ARC DECRA Fellow, Centre for Offshore Foundation Systems (COFS), The University of Western Australia, 35 Stirling Highway, Crawley, WA 6009, Tel: +61 86488 7358, Fax: +61 86488 1044, Email: muhammad.hossain@uwa.edu.au

${ }^{2}$ Professor (PhD, MIEAust), School of Civil, Environmental and Mining Engineering, The University of Western Australia, 35 Stirling Highway, Crawley, WA 6009, Tel: +61 (0)8 6488 8182, Fax: +61 (0)8 6488 1018, Email: yuxia.hu@uwa.edu.au

${ }^{3}$ Former Research Student, School of Civil and Resource Engineering, The University of Western Australia

- Number of Words: 2558 (text only)

- Number of Tables: 1

- Number of Figures: 8 


\title{
Extraction Response of Skirted Foundations and a Spudcan on Sand-Over-Clay Deposits
}

\begin{abstract}
This paper presents a comparison of extraction resistance between spudcan and skirted foundations in sand-over-clay deposits. A series of centrifuge model tests was undertaken on a spudcan and two skirted foundations, varying the length of the skirt relative to the foundation diameter. The thickness of the sand layer was also varied to cover a range of practical interest. It was found that the ultimate breakout forces of the spudcan and 'sealed' skirted foundations in the sand-over-clay deposits are lower than that of a spudcan in single layer clay deposit. On the sand-over-clay deposits, when the skirted foundations are sealed, the breakout forces are $60 \sim 61 \%$ higher than that of the spudcan. However, when the skirted foundations are vented, this difference becomes minimal, regardless of the skirt length and the effective sand layer thickness beneath the foundation, with the height of the sand plug left in the clay layer being similar to the thickness of the sand layer.
\end{abstract}

KEYWORDS: bearing capacity; centrifuge modelling; clays; failure; footings/foundations; offshore engineering; sands 


\section{NOTATION}

A plan area of spudcan at largest section or outer base area of skirted foundation

$c_{\mathrm{v}} \quad$ coefficient of consolidation

D diameter of spudcan at largest section or outer diameter of skirted foundation

$D_{\mathrm{e}} \quad$ effective diameter of object

$d \quad$ penetration depth of foundation base

$d_{\mathrm{br}} \quad$ breakout depth

$I_{\mathrm{D}} \quad$ relative density of sand

$L \quad$ length of skirt

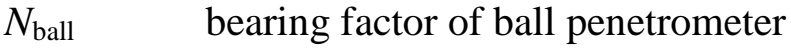

$N_{\text {T-bar }} \quad$ bearing factor of T-bar penetrometer

$Q_{\text {br }} \quad$ breakout force

$Q_{\text {in }} \quad$ maximum installation resistance

$s_{\mathrm{u}} \quad$ undrained shear strength of clay

$s_{\text {us }} \quad$ undrained shear strength of clay at the sand-clay interface

$s_{\mathrm{u}, \mathrm{p}} \quad$ undrained shear strength of clay from penetrometer penetration tests

$s_{\mathrm{u}, \mathrm{e}} \quad$ undrained shear strength of clay from penetrometer extraction tests

$t \quad$ thickness of sand layer 


$\begin{array}{ll}t_{\mathrm{r}, \mathrm{p}} & \text { thickness of sand layer beneath spudcan base (lowest point of largest section) } \\ & \text { or skirt tip } \\ t_{\mathrm{r}, \mathrm{e}} & \text { height of sand plug left in clay layer after extracting spudcan or skirted } \\ & \text { foundation } \\ t_{\mathrm{sk}} & \text { thickness of skirt } \\ V & \text { normalised velocity index } \\ v & \text { penetration rate of object } \\ z & \text { depth below soil surface } \\ \gamma_{\mathrm{c}}^{\prime} & \text { effective unit weight of clay } \\ \gamma_{\mathrm{s}}^{\prime} & \text { effective unit weight of sand }\end{array}$




\section{INTRODUCTION}

Spudcan foundations provide support at the seabed for independent-legged jack-up rigs used in offshore exploratory drilling, installation of new platforms, maintenance work and for hydrocarbon production for fields of limited life. Installing and preloading a mobile jack-up rig on sand-over-clay deposits has been a challenge for the offshore industry, with the potential for severe 'punch-through' failure. Recently, the use of skirted foundations or skirted spudcans, instead of conventional spudcans, has been discussed to mitigate or ease the potential punch-through failure on sand-over clay deposits during installation. Teh et al. (2008a), Gan et al. (2011), and Hossain et al. (2014) have presented promising results that skirted foundation can be an effective alternative at mitigating the risk of punch-through failure for spudcan. However, a question was raised in regards to the extraction resistance, i.e. if the extraction resistance will increase significantly because of using skirted foundations. This paper answers this question presenting spudcan and skirted foundations extraction resistances from a series of centrifuge model tests, while the corresponding penetration resistance profiles were reported in Hossain et al. (2014).

\section{CENTRIFUGE MODELLING}

\subsection{Experimental Program}

The experimental program comprised centrifuge modelling of monotonic installation and extraction of spudcan and skirted foundation in sand-over-clay deposit (Figure 1). The work was carried out at $200 \mathrm{~g}$ in the drum centrifuge at the University of Western Australia (Stewart et al., 1998). The soil was confined within a purpose designed strongbox, with the box mounted within the drum channel. The box has an internal size of 258 (length) $\times 163$ (width) $\times 160$ (depth) $\mathrm{mm}$. Model tests were performed using a spudcan and two skirted foundations of $60 \mathrm{~mm}$ (12 $\mathrm{m}$ in prototype) diameter (Figure 2). The ratios of skirt length to 
diameter $(L / D)$ of the model skirted foundations were 0.25 and 0.5 . The thickness of the skirts was $t_{\mathrm{sk}}=0.008 D$. The drainage hole on the lid (Figure 1) was to allow water egress during skirt installation.

\subsection{Preparation of Sand-Over-Clay Specimen}

A total of three boxes were prepared varying the thickness of the upper sand layer $(t / D=$ 0.25 0.58; Table 1). The sand layer was produced by using super fine silica sand, and the clay layer by using kaolin clay (with the geotechnical properties given in Tables 1 and 2 of Hossain et al., 2014). Clay samples with a uniform strength profile were prepared by consolidating thoroughly mixed, and then de-aired, kaolin slurry at $1 \mathrm{~g}$ in a cell under a final pressure of $200 \mathrm{kPa}$. A layer of clay was cut from the pre-consolidated clay sample according to the size of the strongbox. A medium dense sand layer was then deposited on top of the lower clay layer by raining the sand in water from a drop height of about $100 \mathrm{~mm}$. The total depth of the samples was about $140 \mathrm{~mm}$ (2.33D). In each box with identical soil layer profile, both skirted foundation and spudcan tests were conducted side by side, just avoiding boundary or overlapping effects following Teh et al. (2008b). All tests were carried out with a free water layer above the specimen surface.

\subsection{Soil Strength Determination}

The prepared sand layers produced an average relative density $I_{\mathrm{D}}$ of $44 \%$. For clay beds, characterisation tests were carried out in-flight using a model ball penetrometer, with a diameter of $9 \mathrm{~mm}$ in model scale, and a model T-bar penetrometer, with model dimensions 5 $\mathrm{mm}$ in diameter and $20 \mathrm{~mm}$ in length. The ball and T-bar were penetrated at $v=1 \mathrm{~mm} / \mathrm{s}$ and $1.25 \mathrm{~mm} / \mathrm{s}$ respectively, giving a dimensionless velocity $V=v D_{\mathrm{e}} / c_{\mathrm{v}} \sim 136>30$ (where vertical coefficient of consolidation, $c_{\mathrm{v}}$, of kaolin clay $=2.6 \mathrm{~m}^{2} /$ year; effective area equivalent diameter $D_{\mathrm{e}}=9 \mathrm{~mm}$ for the ball and $11.28 \mathrm{~mm}$ for the T-bar), ensuring undrained conditions 
(Finnie \& Randolph, 1994). The deduced undrained shear strength profiles, using a ball factor of $N_{\text {ball }}=11.17$ (Low et al., 2010) and a T-bar factor of $N_{\text {T-bar }}=10.5$ (e.g. Martin \& Randolph, 2006), are plotted in Figure 3, with the values of extraction strength, $s_{\mathrm{u}, \mathrm{e}}$, given in Table 1. Assembling a worldwide, high-quality database of lightly overconsolidated clays, Low et al. (2010) reported an average ball bearing factor of 11.17 (with respect to the average of triaxial compression, simple shear and triaxial extension shear strengths), with the range being 10.80 11.53. The ball penetrometer used in the centrifuge test program was relatively smooth (roughness about 0.2 ) with area ratio (of the shaft to the ball) 0.25 . A corresponding deep bearing factor was given by Zhou \& Randolph (2011) as 11.20, and can be calculated using the equation proposed by Zhou et al. (2016) as 11.19 . These justify the selection of $N_{\text {ball }}=$ 11.17. For the sand blasted T-bar penetrometer (Stewart \& Randolph, 1991) used in the characterisation tests, a deep bearing factor for a roughness of $\sim 0.4$ can be picked from the nearly exact solutions reported by Martin \& Randolph (2006) as 10.5 (range 9.20 11.94 for roughness $0 \sim 1.0$ ), which is also supported by a long prior experience on centrifuge testing in kaolin clay (e.g. Hossain et al., 2005).

\subsection{Foundation Penetration-Extraction Test}

The process of each test consisted of three stages: installation, operation, and extraction of foundation. The installation of the spudcan was carried out in-flight until the spudcan reached the target depth of about 1.25 1.5 times spudcan diameter. The operation period of the spudcan commenced after reducing the installation load (maximum penetration resistance, $Q_{\text {in }}$ ) on the spudcan by $25 \%$ (consistent with Purwana et al., 2005) to an operational working load. The operation stage was simulated by maintaining a constant vertical load on the spudcan for a duration of 3.25 minutes ( $\sim 3$ months in prototype, which is typical for short term operations). The spudcan was then extracted using a displacement-controlled system. 
For the skirted foundations, the drainage hole was kept open during the skirt installationconsistent with the process used in the field (Alessandrini \& Lebois, 2007). When the foundation lid touched the soil surface, the centrifuge was stopped momentarily for manually shutting the hole, and ramped up back to $200 \mathrm{~g}$. Then the 'sealed' foundation was penetrated to a depth of $1.25 \sim 1.5$ diameter, the installation load on the foundation was reduced by $25 \%$, the load was held for 3.25 minutes, and then the foundation was extracted. For Box 3, two skirted foundation penetration-extraction tests were conducted without shutting the drainage hole to achieve 'vented' extraction. A load cell fitted between the loading arm of the actuator and the foundation shaft measured load-penetration responses in this displacement controlled system.

\section{COMPARISON OF RESULTS ON SPUDCAN AND SKIRTED FOUNDATIONS}

Table 1 provides a summary of all tests conducted. In order to examine the effect of using skirted foundations, extraction response profiles from tests on spudcan and skirted foundations are plotted in Figure 4. For Box B1 and Box B2 $(t / D=0.5 \sim 0.58$, Tests SP1, SK1, SP2, SK2; Figures $4 \mathrm{a}$ and $4 \mathrm{~b}$ ), the values of ultimate breakout force, $Q_{\mathrm{br}}$, for the spudcan Tests SP1 and SP2 are similar (14.98 MN and 14.64 MN respectively) and they occur at a similar breakout depth of $d_{\mathrm{br}} / D=1.18,1.13$. These breakout forces are smaller than that in single layer clay $\left(18.89 \mathrm{MN}\right.$, which is equivalent to $\left.\sim 10 A s_{\mathrm{u}, \mathrm{e}}\right)$ as was reported by Hossain \& Dong (2014) from a series of spudcan extraction tests in kaolin clay. This is because, during penetration, a sand plug was trapped at the base of the spudcan and penetrated in the bottom clay layer with the spudcan. Upon extraction, the spudcan base was separated from the underlying sand plug i.e. the base suction was released, as discussed by Hossain \& Dong (2014) and Hossain et al. (2015) and the evidence is shown in Figure 5. Figure 5 displays the sand plug left in the clay layer by dissecting the layered soil specimen in Box 1 after the extraction of the foundations. It can be seen that, for the spudcan, the height of the sand plug 
left in the clay layer, $t_{\mathrm{r}, \mathrm{e}}$, is similar to the thickness of the sand layer, $t$, as the corresponding effective sand layer thickness during penetration $t_{\mathrm{r}, \mathrm{p}}=t$ (i.e. $t_{\mathrm{r}, \mathrm{e}}=t_{\mathrm{r}, \mathrm{p}}=t$ ). The separation of the spudcan base from the underlying sand plug is also confirmed by a snapshot from a halfspudcan test (from Hossain et al., 2015). Note, this is also evidenced through the dissection of the specimen in Box 2.

It is seen from Figure 4 that the use of a 'sealed' skirted foundation with $L / D=0.5$ increases the breakout force by $60 \sim 61 \%$. This influence reduces to $23 \sim 27 \%$ if the comparison is made with the spudcan breakout force in single layer clay. It should be noted that, during penetration, a sand plug of height $L / D$ was trapped inside the advancing skirt and hence the effective sand plug trapped beneath the penetrating foundation was $t_{\mathrm{r}, \mathrm{p}} / D=t / D-L / D$ (see Figure 1) $=0$ (for Box B1) and 0.08 (for Box B2). During extraction, the sand trapped inside the skirt would have been moved upward with the foundation. The sand plug left in the clay layer displays the sand plug formed underneath the skirt tip with thickness $t_{\mathrm{r}, \mathrm{e}}=t_{\mathrm{r}, \mathrm{p}}$ i.e. zero sand plug for Test SP1 (Box 1, see Figure 5) and $4.8 \mathrm{~mm}(0.08 D)$ sand plug for Test SP2 (Box B2).

Menzies \& Roper (2008) reported case histories from different locations in the Gulf of Mexico. The soils were predominantly normally and lightly overconsolidated clay. Problems were not experienced during spudcan extraction, as highlighted by Menzies \& Lopez (2011). Typical preload range on 12-m diameter spudcans were 35 70 MN. Although it was not given, the corresponding breakout force can be calculated as $0.7 \times 35 \sim 70=24.5 \sim 49 \mathrm{MN}$ following the experimental results presented by Hossain et al. (2015). This range is also shown in Figure 4 and included in Table 1. As such, the breakout forces of 23.16, 24.15 MN resulted from skirted foundations extraction in sand-over-clay should not exceed the jacking up limit i.e. no problems should be experienced during spudcan extraction. 
For tests on Box B3 ( $t / D=0.25$, Tests SP3, SP4; Figure 6), where 'vented' (without shutting the drainage hole) skirted foundations were penetrated and extracted and $t_{\mathrm{r}, \mathrm{p}} / D=0$ and -0.25 , $Q_{\mathrm{br}}$ values of 14.75 and $15.40 \mathrm{MN}$ are very similar to those $(14.64,14.98 \mathrm{MN})$ for the spudcan extraction in Box B1 and B2. This is attributed to the fact that vented extraction was associated with leaving behind the sand plug trapped inside the skirted foundation during penetration i.e. only skirted foundation was extracted. Consequently, the height of the sand plug left in the clay layer $t_{\mathrm{r}, \mathrm{e}} / D=t / D$. The evidence is given in Figure 7. As such, in the field, if skirted foundations are used for mitigating punch-through on sand-over-clay deposits, a low breakout force can also be assured if the drainage hole is kept open (i.e. vented extraction is ensured).

\section{INSTALLATION DEPTH}

In the previous section, the factual data from a series of centrifuge model tests are presented, with the effect of relative installation depth not considered. Three cases have been discussed including (i) Case I - spudcan on single layer; (ii) Case II - spudcan on sand-over-clay and (iii) Case III - (sealed or vented) skirted foundation on sand-over-clay (see Figure 8). For this discussion, an ideal case with NC or lightly overconsolidated clay deposit (Case I) can be considered where a spudcan may penetrate 2 5D (Menzies \& Roper, 2008; Menzies \& Lopez, 2011). If there is a naturally deposited sand layer above that clay layer or a sand layer is spread artificially (Case II), the spudcan penetration depth (and hence required jack-up leg length) and breakout force could be reduced (Hossain, 2014; Hossain \& Dong, 2014). Hossain et al. (2015) showed that an addition of $2 \mathrm{~m}$ sand layer has yielded a 15 17\% reduction of spudcan penetration depth under a given preload and hence the breakout force as much as $50 \%$. However, depending on the relative thickness $(t / D)$ and density $\left(I_{\mathrm{D}}\right)$ of the sand layer and the undrained shear strength of the underlying clay layer, the spudcan may experience a punch-through incident, which can be assessed using the methods recommended by the 
recently finalised version of ISO guidelines 19905-1 (ISO, 2012) or the methods proposed by Lee et al. (2013b) and $\mathrm{Hu}$ et al. (2015a). From three series of centrifuge tests on spudcan foundations penetrating dense sand $\left(I_{\mathrm{D}} \geq 88 \%\right)$-over-soft clay deposits, Teh et al. (2008b, 2010) and Lee et al. (2013a) reported that no punch-through occurred for $t / D=t_{\mathrm{r}} / D \leq 0.3$ (Teh et al. 2008b, 2010) and 0.21 (Lee et al. 2013a). For spudcan penetration in medium dense sand $\left(I_{\mathrm{D}}=44 \%\right.$ and $\left.74 \%\right)$-over-soft clay deposits, a slightly higher value (of about $t / D$ $\left.=t_{\mathrm{r}} / D \leq 0.4\right)$ for occurring punch-through can be marked from the centrifuge test data presented by $\mathrm{Hu}$ et al. $(2014,2015 b)$.

The use of an alternative skirted foundation (with diameter equal to the spudcan diameter and appropriate skirt length; Case III) will lessen or mitigate the potential punch-through hazard. However, under a given preload, the skirted foundation may enhance the installation depth by up to $10 \%$ (Hossain et al., 2014), though this penetration depth will still be lower than that of the spudcan penetrating in the single layer of clay deposit i.e. without the sand layer on the top (Case I). With a sand layer on the top, the breakout force during extraction of a vented skirted foundation becomes similar to that of a spudcan, and these forces are significantly lower than those of a spudcan in single layer clay.

Therefore if an artificially spread sand layer on top of a clay layer is combined with the use of a skirted foundation, two benefits, compared to a spudcan on a single layer clay deposit, may be obtained including (i) reduction of foundation penetration depth under a given preload and hence reduction of required jack-up leg length; (ii) reduction of breakout force during extraction, with the mitigation or lessening of potential punch-through. 


\section{CONCLUDING REMARKS}

The experimental results presented in this paper have confirmed that

(a) In general, the ultimate breakout forces of the spudcan and 'sealed' skirted foundations in the sand-over-clay deposits are lower than that of a spudcan in single layer clay.

(b) The use of the skirted foundations for mitigating potential punch-though on the sand-over-clay deposits results in a 60 61\% increase of breakout force, compared to that of the spudcan, if the skirted foundations are extracted under sealed condition.

(c) Extraction of the vented skirted foundations results in the ultimate breakout forces similar to that of the spudcan in a sand-over-clay deposit with the upper sand layer thickness of 0.25 foundation diameter and effective sand layer thickness beneath the skirted foundations of 0 and -0.25 foundation diameter, with the height of the sand plug left in the clay layer being similar to the thickness of the sand layer.

(d) Comparing to a spudcan on a single layer of clay deposit, if a sand layer spread artificially above the clay layer is combined with the use of a skirted foundation, the foundation penetration depth under a given preload, and hence required jackup leg length, and breakout force during extraction may reduce along with mitigation or ease of potential punch-through.

The effect of various installation depth and operational period will be investigated in future. 


\section{ACKNOWLEDGEMENTS}

The research presented here was undertaken with support from the Australian Research Council (ARC) Discovery Grant (DP1096764). The first author is an ARC Discovery Early Career Researcher Award (DECRA) Fellow and is supported by the ARC Project DE140100903. The work forms part of the activities of the Centre for Offshore Foundation Systems (COFS), currently supported as a node of the Australian Research Council Centre of Excellence for Geotechnical Science and Engineering and as a Centre of Excellence by the Lloyd's Register Foundation. This support is gratefully acknowledged, as is the assistance of the drum centrifuge technician, Mr. Bart Thompson. 


\section{REFERENCES}

Alessandrini, V. \& Lebois, G. (2007). A case study of using very large skirt can for selfinstalling platform foundations. Proc. Offshore Technology Conference, Houston, OTC 18688.

Finnie, I. M. \& Randolph, M. F. (1994). Bearing response of shallow foundations in uncemented calcareous soil. Proc., Int. Conf. Centrifuge '94, Singapore, 535-540.

Gan, C. T., Teh, K. L., Leung, C. F., Chow, Y. K. \& Swee, S. (2011). Behaviour of skirted footings on sand overlying clay. Proc. 2nd Int. Symp. Frontiers in Offshore Geotechnics, ISFOG, Perth, pp. 415-420.

Hossain, M. S., Hu, Y., Randolph, M. F. \& White, D. J. (2005). Limiting cavity depth for spudcan foundations penetrating clay. Géotechnique 55, No. 9, 679-690.

Hossain, M. S. \& Dong, X. (2014). Extraction of spudcan foundations in single and multilayer soils. J. Geotechnical and Geoenvironmental Engineering, ASCE 140, No. 1, 170-184.

Hossain, M. S., Hu, Y. \& Ekaputra, D. (2014). Skirted foundation to mitigate spudcan punchthrough on sand-over-clay. Géotechnique 64, No. 4, 330-340.

Hossain, M. S., Safinus, S. \& Cassidy, M. J. (2015). Using a thin sand layer to ease spudcan extraction in clay. Canadian Geotechnical Journal 52, No. 8, 1023-1034.

Hu, P., Stanier, S. A., Cassidy, M. J. \& Wang, D. (2014). Predicting peak resistance of spudcan penetrating sand overlying clay. J. Geotech. Geoenviron. Eng., ASCE 140, No. 2, 04013009-1-12.

Hu, P., Wang, D., Stanier, S. A. \& Cassidy, M. J. (2015a). Assessing the punch-through hazard of a spudcan on sand overlying clay. Géotechnique 65, No. 11, 883-896. 
Hu, P., Wang, D., Cassidy, M. J., Stanier, S. A. (2015b). Effect of footing shape on penetration in sand overlying clay. Int. J. Physical Modelling in Geotechnics, http://dx.doi.org/10.1680/jphmg.15.00013.

ISO (2012). Petroleum and natural gas industries - Site specific assessment of mobile offshore units - Part 1: Jack-ups. International Organization for Standardization, ISO 19905-1.

Lee, K. K., Cassidy, M. J. \& Randolph, M. F. (2013a). Bearing capacity on sand overlying clay soils: experimental and finite-element investigation of potential punch-through failure. Géotechnique 63, No. 15, 1271-1284.

Lee, K. K., Randolph, M. F. \& Cassidy, M.J. (2013b). Bearing capacity on sand overlying clay soils: a simplified conceptual model. Géotechnique 63, No. 15, 1285-1297.

Low, H. E., Lunne, T., Andersen, K. H., Sjursen, M. A., Li, X. \& Randolph, M. F. (2010). Estimation of intact and remoulded undrained shear strengths from penetration tests in soft clays. Géotechnique 60, No. 11, 843-859.

Martin, C. M. \& Randolph, M. F. (2006). Upper-bound analysis of lateral pile capacity in cohesive soil. Géotechnique 56, No. 2, 141-145.

Menzies, D. \& Roper, R. (2008). Comparison of jackup rig spudcan penetration methods in clay. Proc. Offshore Technology Conference, Houston, OTC 19545.

Menzies, D. \& Lopez, C. R. (2011). Four atypical jack-up rig foundation case histories. Proc. 13th Int. Conf. The Jack-up Platform: Design, Construction and Operation, London.

Purwana, O. A., Leung, C. F., Chow, Y. K. \& Foo, K. S. (2005). Influence of base suction on extraction of jack-up spudcans. Géotechnique 55, No. 10, 741-753. 
Stewart, D. P., Boyle, R. S. \& Randolph, M. F. (1998). Experience with a new drum centrifuge. Proc. Int. Conf. on Centrifuge '98, pp. 35-40. Rotterdam: Balkema.

Stewart, D. P. \& Randolph, M. F. (1991). A new site investigation tool for the centrifuge. Proc. Int. Conf. Centrifuge '91, pp. 531-538. Rotterdam: Balkema.

Teh, K. L., Gan, C. T., Hu, E. H. J., Leung, C. F. \& Chow, Y. K. (2008a). A comparison of penetration behaviour of spudcan and skirted footing in sand overlying clay'. Proc. 2nd Jack-up Asia Conf. and Exhibition, Singapore.

Teh, K. L., Cassidy, M. J., Leung, C. F., Chow, Y. K., Randolph, M. F. \& Quah, C. K. (2008b). Revealing the bearing capacity mechanisms of a penetrating spudcan through sand overlying clay. Géotechnique 58, No. 10, 793-804.

Teh, K. L., Leung, C. F., Chow, Y. K. \& Cassidy, M. J. (2010). Centrifuge model study of spudcan penetration in sand overlying clay. Géotechnique 60, No. 11, 825-842.

Zhou, M., Hossain, M. S., Hu, Y. \& Liu, H. (2016). Scale issues and interpretation of ball penetration in stratified deposits in centrifuge testing. J. Geotechnical and Geoenvironmental Engineering, ASCE 142, No. 5, 04015103-1-12.

Zhou, H. \& Randolph, M. F. (2011). Effect of shaft on resistance of a ball penetrometer. Géotechnique 61, No. 11, 973-981, http://dx.doi.org/10.1680/geot.9.P.062. 
Table 1. Summary of centrifuge tests conducted on spudcan and skirted foundations

\begin{tabular}{|c|c|c|c|c|c|c|c|c|c|c|c|c|c|c|c|}
\hline Box & Test & $\begin{array}{l}\text { Foundation } \\
\text { diameter, } \\
\qquad D: \mathrm{m}^{\#}\end{array}$ & $\begin{array}{l}\text { Skirt } \\
\text { length, } \\
L: \mathrm{m}^{\#}\end{array}$ & $\begin{array}{c}\text { Sand } \\
\text { thickness, } \\
\qquad t: \mathrm{m}^{\#}\end{array}$ & $L / D$ & $t / D$ & $t_{\mathrm{r}} / D$ & $\begin{array}{c}\text { Sand } \\
\text { relative } \\
\text { density, } \\
I_{\mathrm{D}}: \%\end{array}$ & $\begin{array}{c}\text { Sand } \\
\text { effective } \\
\text { unit } \\
\text { weight, } \\
\gamma^{\prime} \text { : } \\
\mathrm{kN} / \mathrm{m}^{3}\end{array}$ & $\begin{array}{c}\text { Clay } \\
\text { undrained } \\
\text { shear } \\
\text { strength, } \\
s_{\mathrm{u}, \mathrm{p}}, s_{\mathrm{u}, \mathrm{e}}: \\
\mathrm{kPa}\end{array}$ & $\begin{array}{c}\text { Clay } \\
\text { effective } \\
\text { unit } \\
\text { weight, } \\
\gamma_{\mathrm{c}}^{\prime} \text { : } \\
\mathrm{kN} / \mathrm{m}^{3}\end{array}$ & $\begin{array}{c}\text { Depth at } \\
Q_{\mathrm{br}}, \\
d_{\mathrm{br}} / D\end{array}$ & $\begin{array}{c}\text { Breakout } \\
\text { force, } \\
Q_{\mathrm{br}}: \mathrm{MN}\end{array}$ & $\begin{array}{l}\text { Assumed } \\
\text { breakout } \\
\text { force in } \\
\text { single } \\
\text { layer clay } \\
\text { (with } s_{\mathrm{u}, \mathrm{e}} \\
=16.7 \\
\mathrm{kPa} \text { ): } \mathrm{MN}\end{array}$ & $\begin{array}{c}0.7 \\
\text { Preload } \\
\text { range }\left(V_{\mathrm{p}}\right. \\
=35 \sim 70 \\
\mathrm{MN}): \mathrm{MN}\end{array}$ \\
\hline \multirow{2}{*}{ B1 } & SP1* & \multirow{5}{*}{12} & - & \multirow{2}{*}{6} & - & \multirow{2}{*}{0.50} & 0.50 & \multirow{2}{*}{44} & \multirow{2}{*}{9} & \multirow{2}{*}{$23.5,16.7$} & \multirow{2}{*}{7.5} & 1.18 & 14.98 & \multirow{5}{*}{18.89} & \multirow{5}{*}{$24.5 \sim 49.0$} \\
\hline & SK $1 *$ & & 6 & & 0.50 & & 0.00 & & & & & 1.06 & 24.15 & & \\
\hline \multirow{2}{*}{ B2 } & SP2 & & - & \multirow{2}{*}{7} & - & \multirow{2}{*}{0.58} & 0.58 & \multirow{2}{*}{44} & \multirow{2}{*}{9} & \multirow{2}{*}{$23.5,16.7$} & \multirow{2}{*}{7.5} & 1.13 & 14.64 & & \\
\hline & SK2 & & 6 & & 0.50 & & 0.08 & & & & & 1.04 & 23.16 & & \\
\hline B3 & SK3 & & 3 & 3 & 0.25 & 0.25 & 0.00 & 44 & 9 & $23.5,16.7$ & 7.5 & 1.03 & 14.75 & & \\
\hline
\end{tabular}

*SP: Spudcan foundation; SK: Skirted foundation

\# In prototype scale 


\section{Number of Figure: 8}

Figure 1. Schematic of spudcan and skirted foundation on sand-over-clay deposit

Figure 2. Model spudcan and skirted foundations

Figure 3. Shear strength profile from penetrometer tests $\left(N_{\text {ball }}=11.17, N_{\text {T-bar }}=10.5\right.$; '-ve' indicates extraction)

Figure 4. Comparison of extraction resistance profiles between spudcan and sealed skirted foundations (Table 1; '-ve' indicates extraction): (a) $t D=0.5$ (Tests SK1 and SP1; Box B1); (b) $t / D=0.58$ (Tests SK2 and SP2; Box B2)

Figure 5. Effect of effective sand layer thickness, $t_{\mathrm{r}} / D$, on trapping of sand plug and spudcan base venting upon extraction, and showing sand plug left at extraction depth (spudcan: $t_{\mathrm{r}} / D=0.5$ and skirted foundation: $t_{\mathrm{r}} / D=0$, Box B1, Table 1)

Figure 6. Extraction resistance profiles of vented skirted foundations $(t D D=0.25$, Tests SK4 and SK5, Box B3;Table 1; '-ve' indicates extraction)

Figure 7. Effect of venting upon the sand plug left at extraction depth (skirted foundation: $t / D=L / D=0.25, t_{\mathrm{r}} / D=0$, Test SK3, Box B3; Table 1)

Figure 8. Schematic presentation of three cases considered 


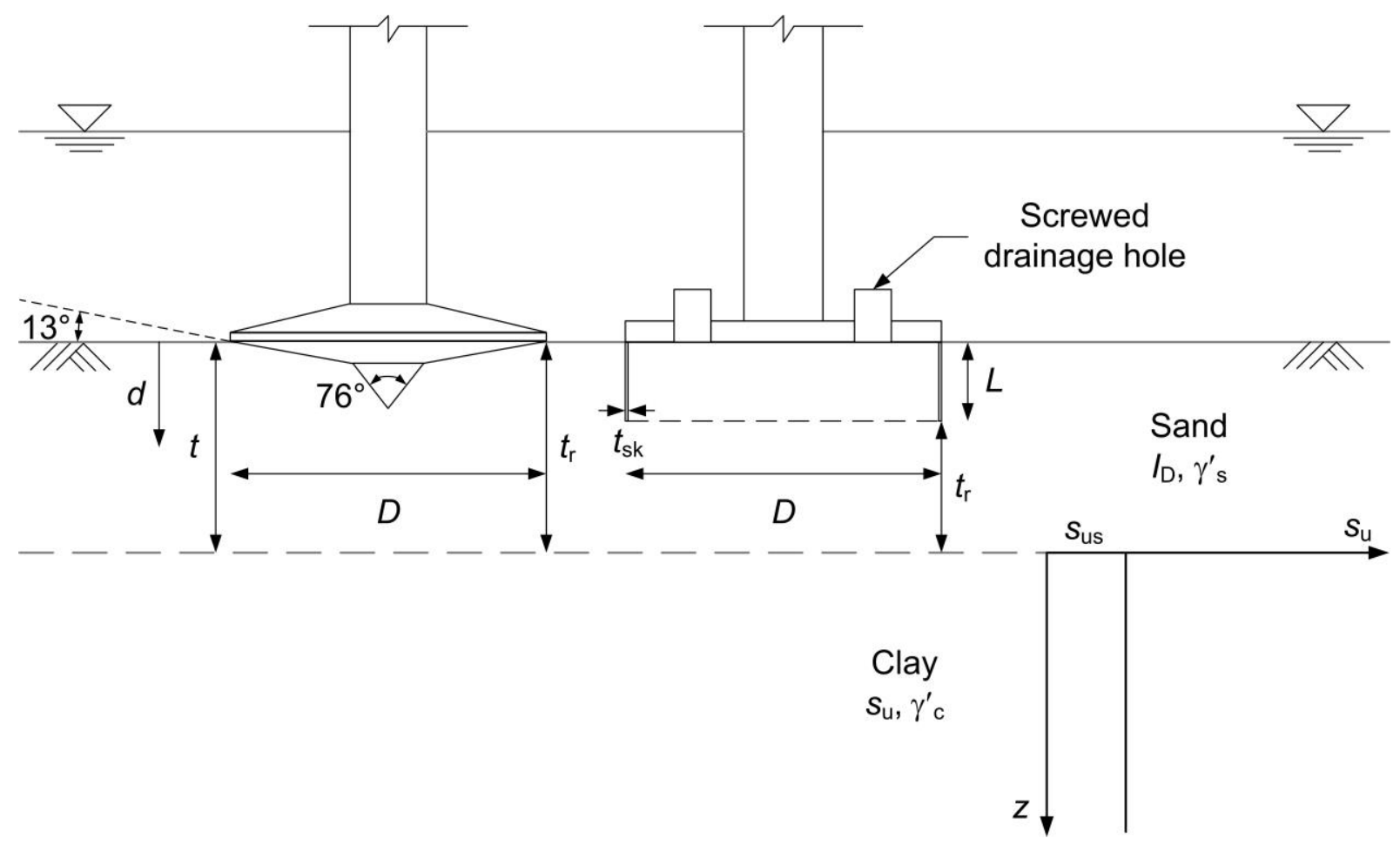

Figure 1. Schematic diagram of spudcan and skirted foundation on sand-over-clay deposit 


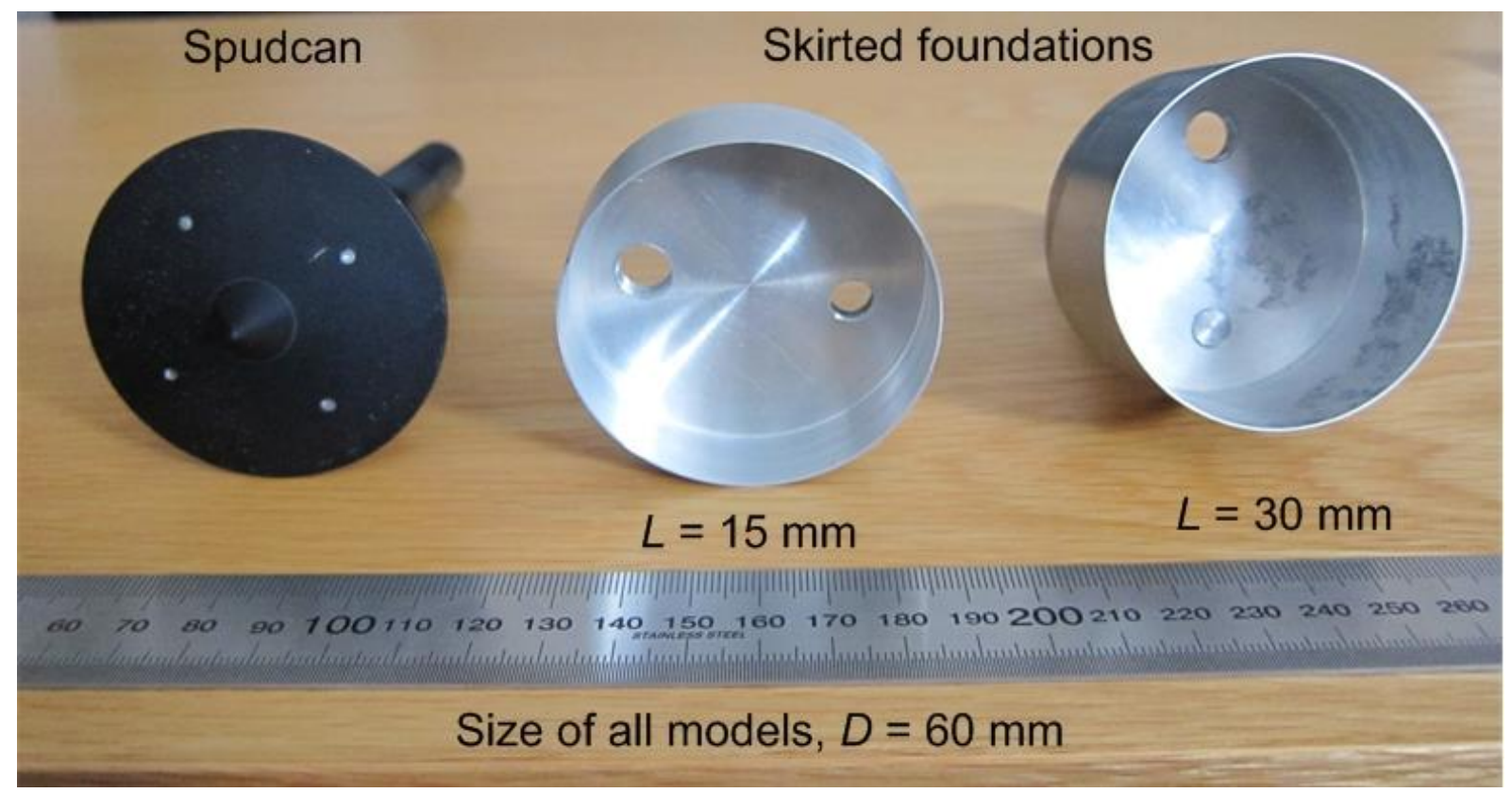

Figure 2. Model spudcan and skirted foundations 


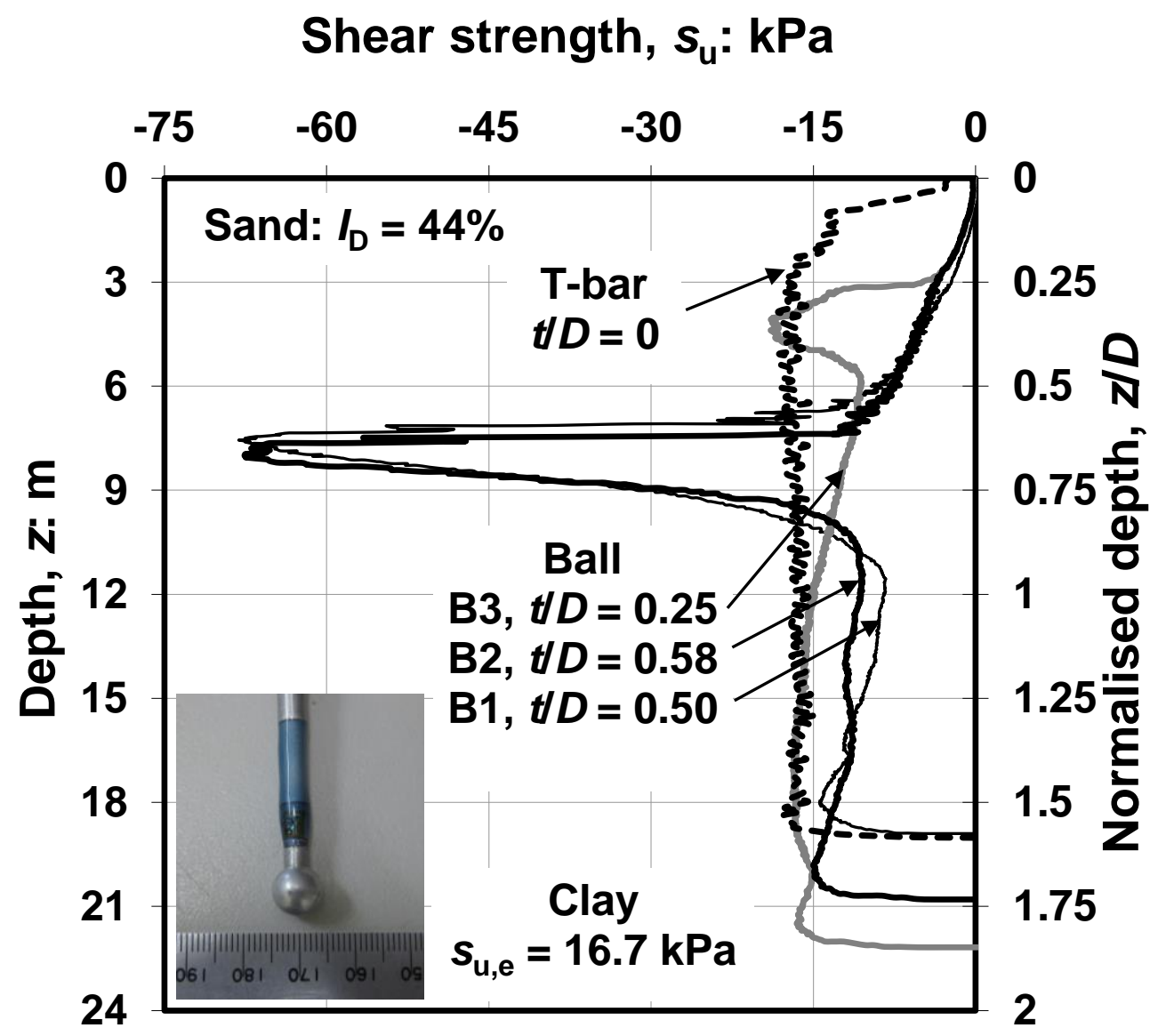

Figure 3. Shear strength profile from penetrometer extraction tests $\left(N_{\text {ball }}=11.17, N_{\text {T-bar }}\right.$ $=10.5$; '-ve' indicates extraction) 
Extraction resistance, $Q_{\mathrm{e}}: M N$

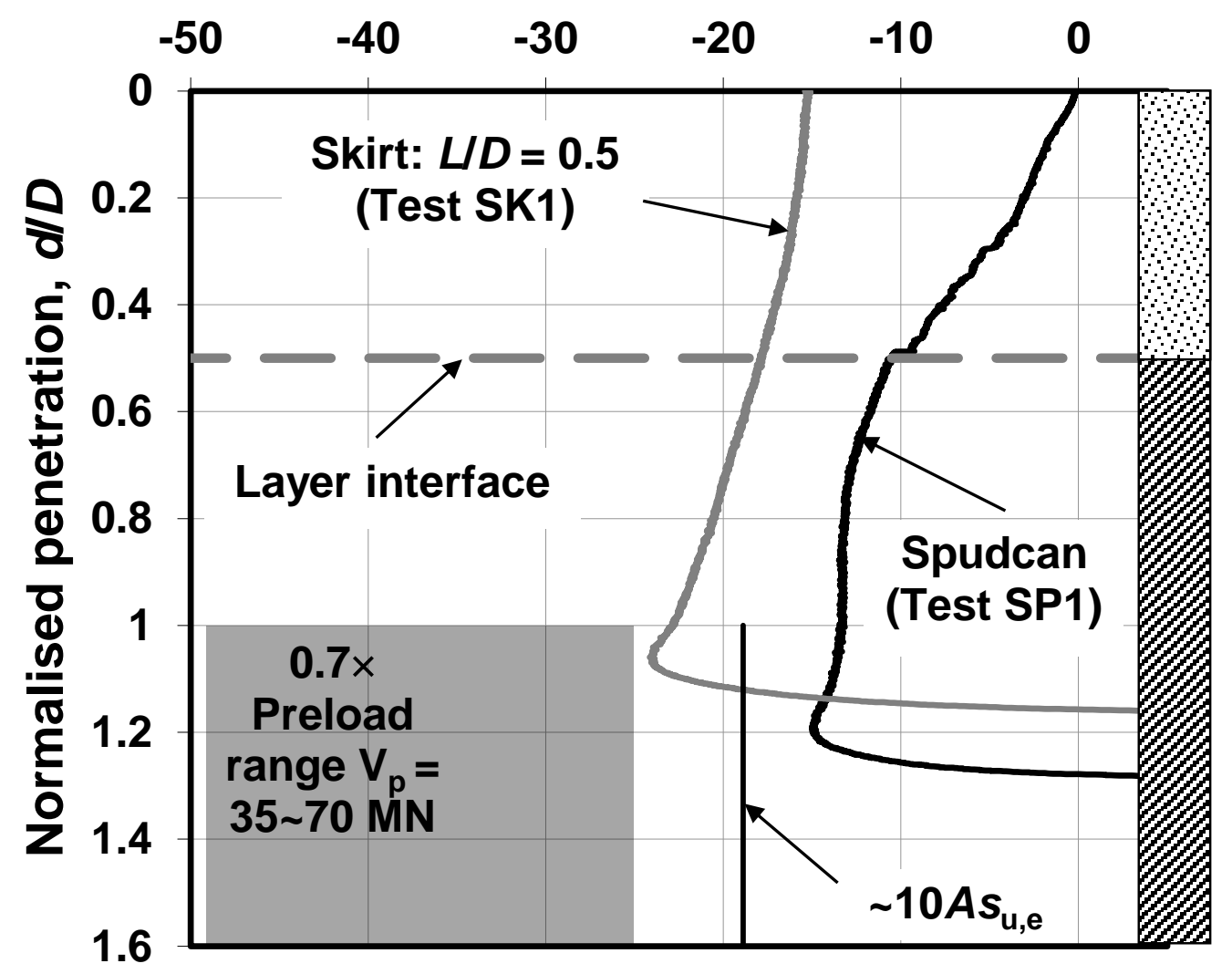

(a) $t / D=0.5$ (Tests SK1 and SP1; Box B1) 
Extraction resistance, $Q_{\mathrm{e}}: \mathrm{MN}$

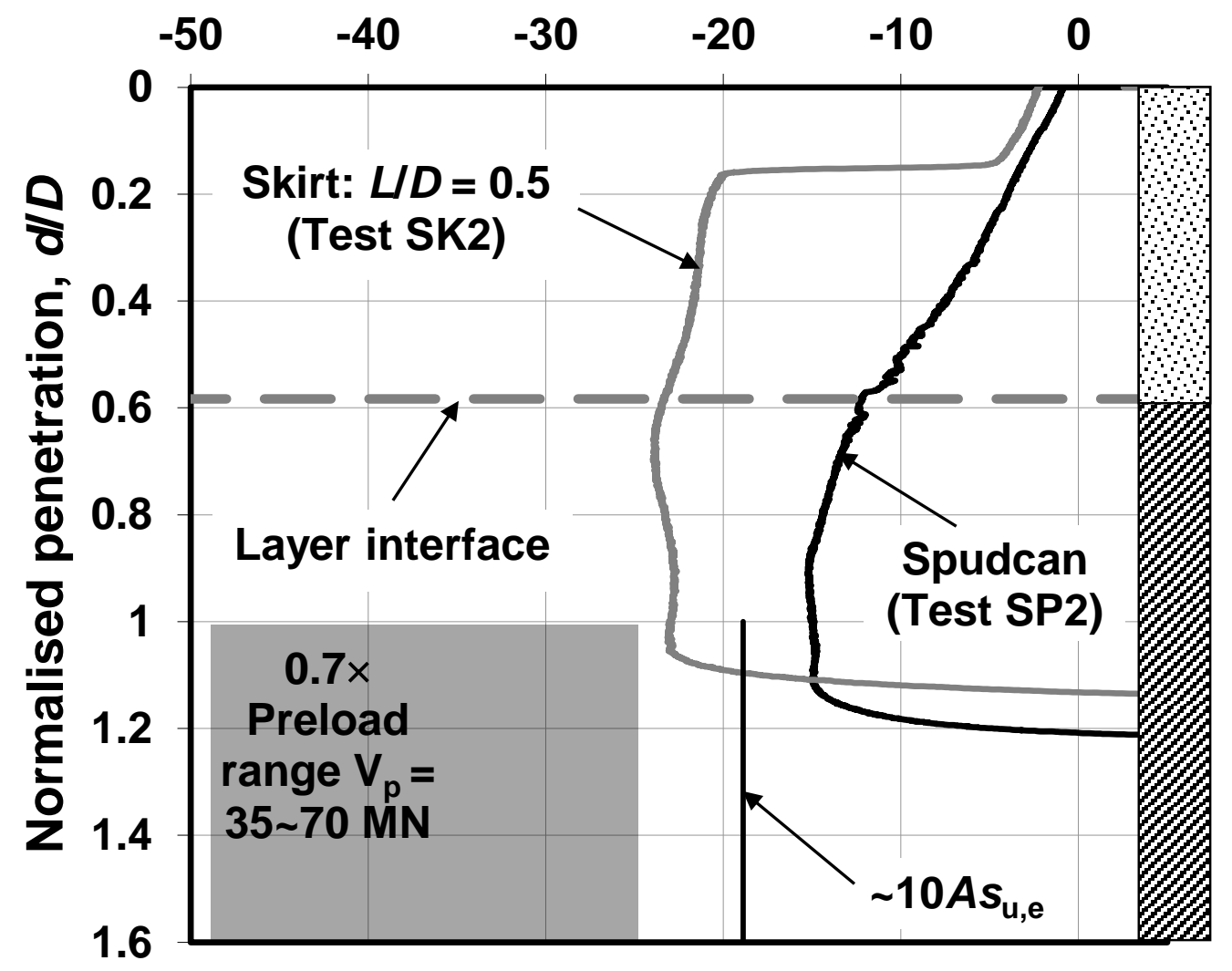

(b) $t / D=0.58($ Tests SK2 and SP2; Box B2)

Figure 4. Comparison of extraction resistance profiles between spudcan and sealed skirted foundations (Table 1; '-ve' indicates extraction) 


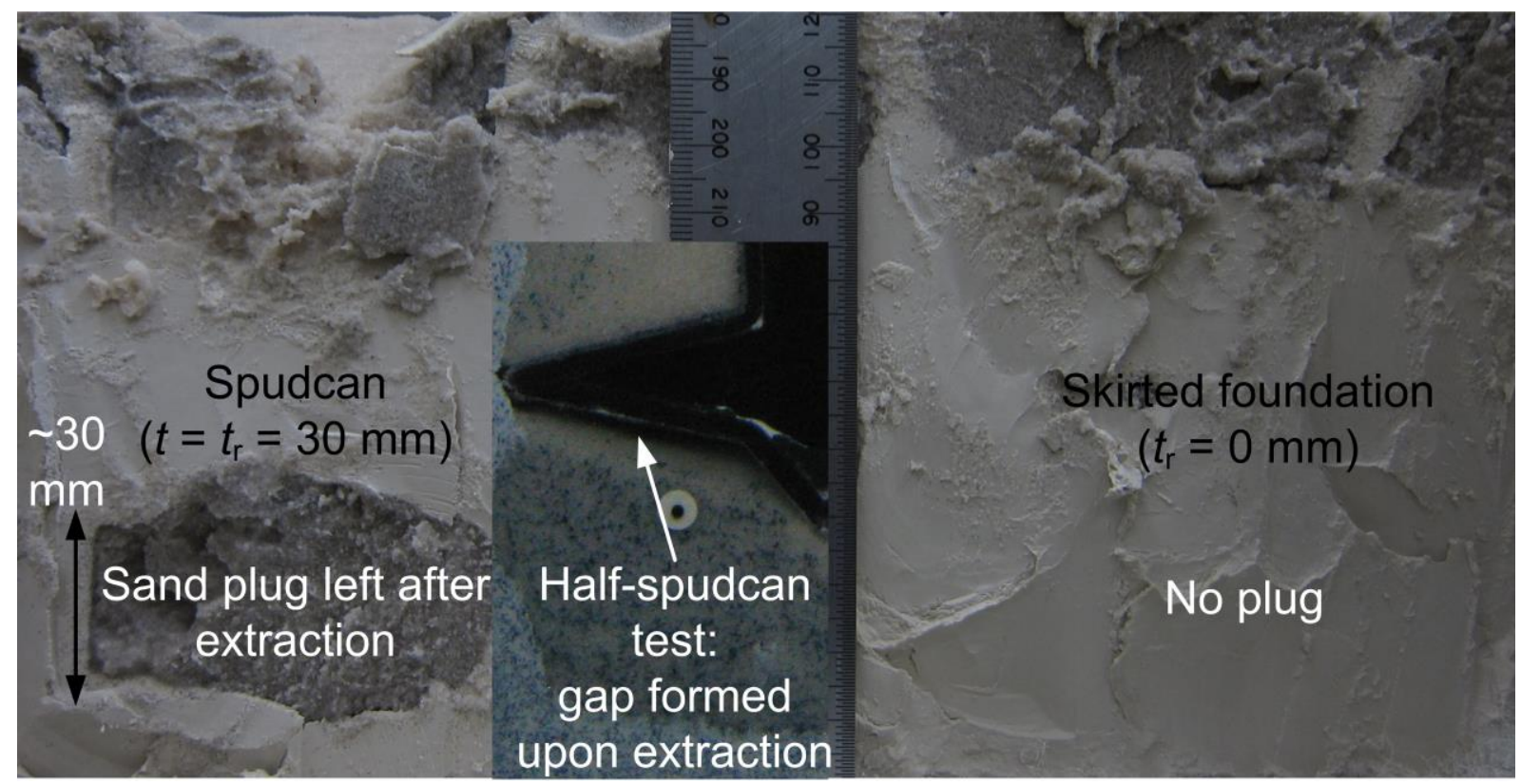

Figure 5. Effect of effective sand layer thickness, $t_{\mathrm{r}} / D$, on trapping of sand plug and spudcan base venting upon extraction, and showing sand plug left at extraction depth (spudcan: $t_{\mathrm{r}} / D=0.5$ and skirted foundation: $t_{\mathrm{r}} / D=0$, Box B1, Table 1) 
Extraction resistance, $Q_{\mathrm{e}}: \mathrm{MN}$

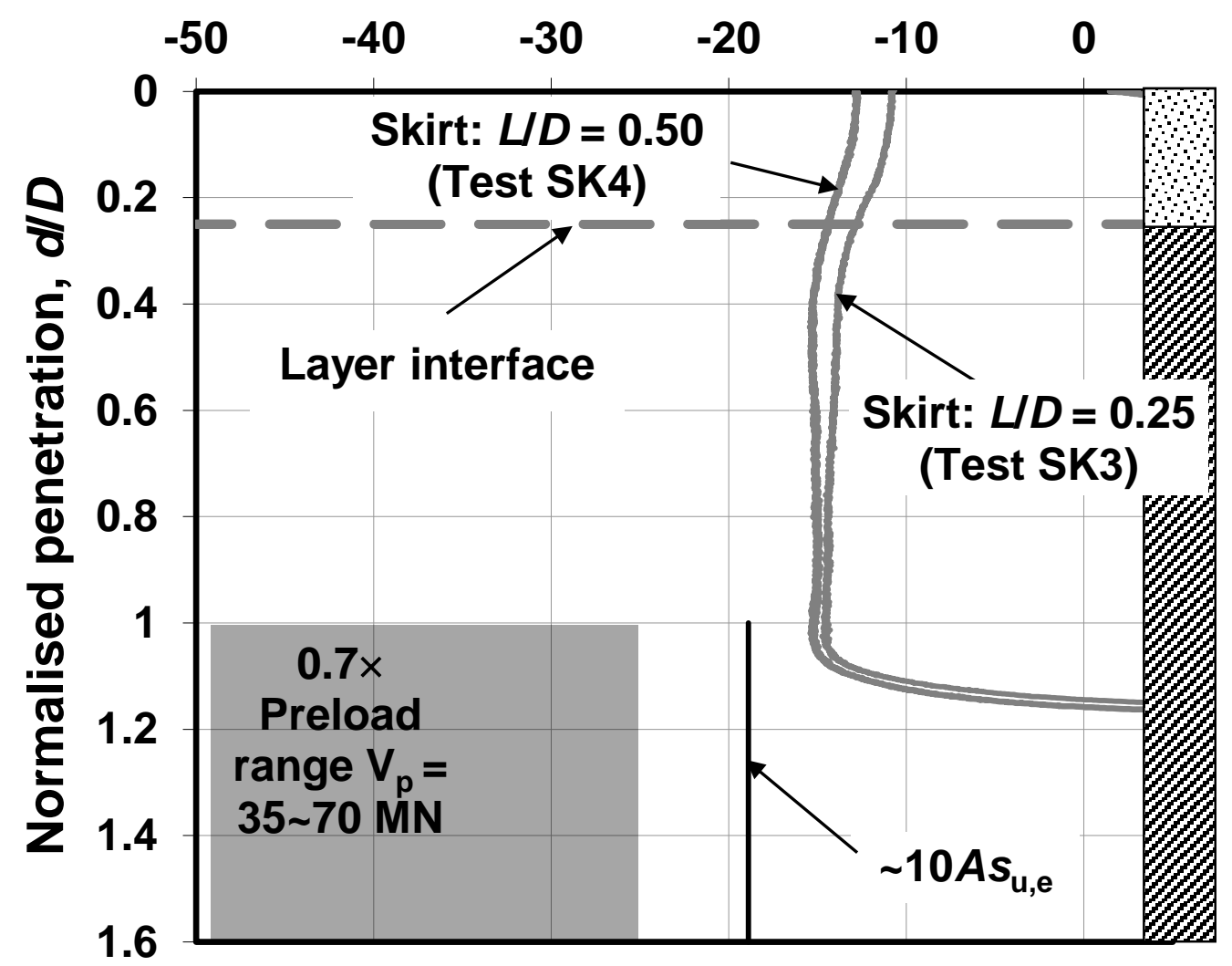

Figure 6. Extraction resistance profiles of vented skirted foundations $(t D=0.25$, Tests SK3 and SK4, Box B3; Table 1; '-ve' indicates extraction) 
Skirted-foundation

$(t=L=15 \mathrm{~mm}$

$$
t_{\mathrm{r}}=0 \mathrm{~mm} \text { ) }
$$

\section{Sand plug inside} skirt left after

extraction

Figure 7. Effect of venting upon the sand plug left at extraction depth (skirted foundation: $t / D=L / D=0.25, t_{\mathrm{r}} / D=0$, Test SK3, Box B3; Table 1) 


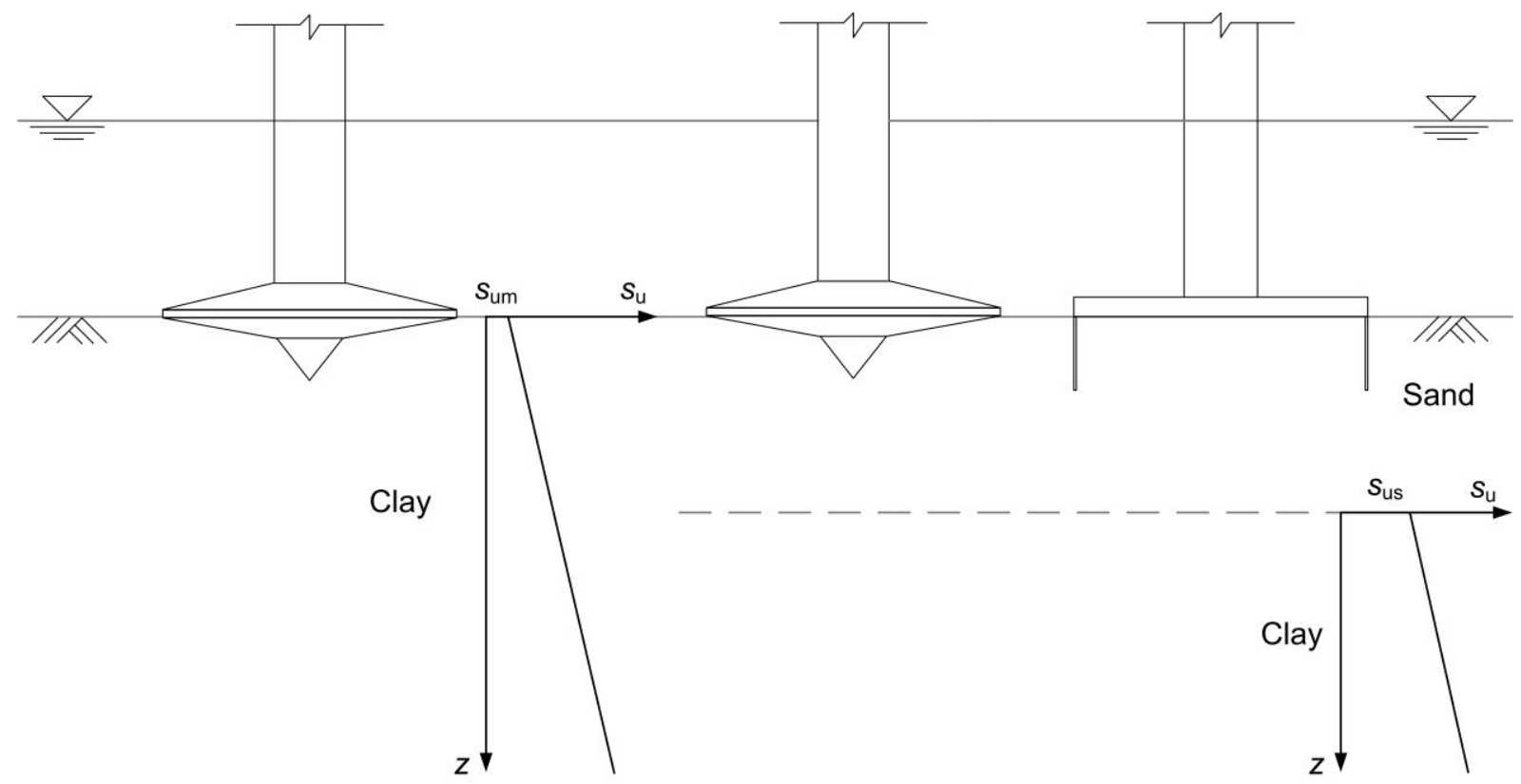

Case I: Spudcan on clay

Case II: Spudcan on sand-over-clay
Case III: Skirted foundation on sand-over-clay

Figure 8. Schematic presentation of three cases considered 